\title{
The Utilization of Agricultural and Food Industry Wastes as Feed of Grower Pigs in Manokwari Regency West Papua
}

\author{
Trisiwi Wahyu Widayati, Bernaddeta Wahyunilrianti Rahayu, Dwi Djoko Rahardjo and \\ Budi Santoso \\ Department of Animal Science, University of Papua, Manokwari, Indonesia \\ Corresponding author email: b.santoso@unipa.ac.id
}

\begin{abstract}
The aim of this study was to find out the potential of agricultural and food industry wastes as the constituents of pig feed to improve pigs' performance and to reduce the feeding cost. This study was conducted at ManokwariRegency, West Papua Province.The agricultural and food industry wastes were collected from two traditional market, and foursmall-scale food industries. All materials used as feed were proximately analyzed to determine their nutritional values. Average daily gain, feed consumption and feed coversion ratio were taken to determine the pigs performance. Feed cost using local market prices was estimated in knowing the ability of agricultural and food industry wastes to substitutes commercial feed. The result of this research indicates that the use of agricultural and food industries wastes as an alternative components of pigs' feed to substitute the commercial feed do not reduce the pigs' performance and production.Among three feeds that use of agricultural and food industry wastes, feed with the combination of $75 \%$ waste and $25 \%$ commercial feed had the best feed conversion ratio, namely 2.36 . On the other hand, a mixture of $25 \%$ wastes and $75 \%$ commercial feed was the most economic one, and able to reduce the feeding cost of grower pig up to $48.00 \%$.
\end{abstract}

Keywords: agricultural waste, food industry wastes, grower period, pig, feed

Abstrak. Tujuan penelitan ini adalah untuk mengetahui potensi limbah pertanian dan limbah industri pangan sebagai penyusun pakan babi untuk meningkatkan penampilan dan menurunkan biaya pakan.Penelitian ini dilaksanakan di Kabupaten Manokwari, Provinsi Papua Barat.Limbah pertanian dan limbah industri pangan diambil dari 2 pasar tradisional dan 4 industri pangan skala kecil.Semua bahan yang digunakan sebagai pakan dianalisis proksimat untuk mengetahui nilai nutrisinya. Rata-rata pertambahan bobot badan harian, konsumsi pakan dan konversi pakan diambil untuk mengetahui penampilan babi.Biaya pakan dihitung menggunakan harga pasar lokal untuk mengetahui kemampuan limbah pertanian dan industri pangan menggantikan pakan komersil. Hasil penelitian mengindikasikan bahwa penggunaan limbah pertanian dan industri pangan sebagai komponen alternatif pengganti pakan komersil tidak menurunkan penampilan dan produksi babi. Diantara pakan yang menggunakan limbah pertanian dan industri pangan, pakan dengan kombinasi 50\% limbah dan $50 \%$ pakan komersil menghasilkan rasio konversi pakan terbaik yaitu 2,64 . Sebaliknya kombinasi $25 \%$ limbah dan $75 \%$ pakan komersil adalah pakan yang paling ekjonomis dan mampu menurunkan biaya pakan babi periode pertumbuhan sampai $48.00 \%$.

Kata kunci: limbah pertanian, limbah industri pangan, periode pertumbuhan, babi, pakan

\section{Introduction}

Zero waste is a concept that has long been applied by several countries in the world including America, Australia, Sweden and New Zealand and several European countries. This concept considers that waste should be minimized wherever possible, through various methods including the process of reduce, reuse and recycle waste into useful material.
Agricultural and the food industry activities produce some organic wastes and by-products commonly known as food waste. Gustavsson et al. (2011) revealed that food waste can occur due to the inefficient handling of agricultural production, post-harvest handling, storage, processing, distribution and consumption of those products. In developing countries, less waste is well managed due to the weak infrastructure supporting production and the 
lack of integration of environmental management with industry, which causes a lot of food to be wasted. In the previous studies of food waste in the United States, Venkat (2011); Thi et al. (2015) stated that there had been an economic loss of US $\$ 197.68$ billion per year due to wasted food waste. These wastes included vegetables, fish, and legumes which were wasted due to inefficiency in retail and consumer in America. Moreover, Stenmarck et al., (2016) reported that there were around 88 million tons of foodwaste each year, according to ca. $173 \mathrm{~kg}$ per capita lost and causing economic losses of 143 billion $€$ each year.

Without good handling, the waste not only reduces the economic potential of food waste but also impacts on greenhouse emmisions. There are emissions of around 3.3 billion tons of $\mathrm{CO}^{2}$ into the atmosphere per year due to neglect of handling waste. Therefore, the comprehensive management in managing agricultural waste and the food industry. According to study by Thi et al. (2015), in some countries, which have high demand for animalbased food products, such as Japan, South Korea and Taiwan utilizing food waste as part of the animal feed with a composition from 33 to $81 \%$. Even EPA U.S. recommended methods for managing waste into animal feed rather than managing it into other forms such as biofuel, compost, stockpiling or combustion.

In livestock business, the cost of feed takes a large portion, which ranges from 44.66 to $55 \%$ of the total production cost Warouw et al. (2014), Kueain et al. (2017). The high price of feeds is due to the main feed ingredients that make up feeds competing with human food such as corn and soybeans. Therefore, the utilization of food waste as an alternative animal feed is expected to provide a role as an economical substitution feed, easily obtained continuously without reducing its role in performance of livestock production.

Pig farms have considerable potential to be developed in the provinces of Papua and West
Papua. According to data from the Directorate General of Livestock and Animal Health (2017), the number of pig populations in the two provinces in 2018, were 871,808 and 82,500 heads, respectively. The indigenous Papuans like to raise pigs because pigs have high economic, social and cultural values. The finisher pig has a price that varies considerably from IDR 5,000,000 (355 USD) to IDR 8,000,000 (567 USD).The highest price is obtained when pigs are needed for traditional ceremonies.

In general, the pig business in West Papua, including in the Manokwari city, still encounters considerable constraints on high feed costs and the ingredients are not continuously available. Therefore, it is needed to use alternative, one of which comes from agricultural and industrial waste around Manokwari. The results of a study by the Faculty of Animal Science (2014) showed that there were several agricultural wastes such as fish waste, rice bran, vegetable waste with the production of $1,000,11,586.60,546.00 \mathrm{~kg} /$ day and there were food industry wastes including soybean curd waste, soybean skin, mung bean skin, bananas skin, taro skin with production of 2,400, 55, 83.4, 127.50, 11.4 kg/day, respectively. The crude protein values of these wastes varied greatly from 4.6 to $31.21 \%$. Thus, the food and industrial waste is expected to be an alternative source of pig feed. The purpose of this study was to determine the performance of grower pig production fed agricultural and food industry waste-based feeds as well as the reduction level of agricultural and food industry waste-based feed to commercial feed.

\section{Materials and Methods}

\section{Location of study}

The experiment was carried out from June to August 2018 at the Animal Research Laboratory of Universitas Papua in Manokwari, Indonesia $\left(134^{\circ} 04^{\prime}\right.$ longitude and $00^{\circ} 48^{\prime}$ latitude) with a mean altitude of $110 \mathrm{~m}$. 
Average temperature is $37^{\circ} \mathrm{C}$ with daily variations from $37-39^{\circ} \mathrm{C}$.

\section{Animal, Feed and Experimental Design}

Four male local pigs with an initial body weight of $22.63 \pm 2.53 \mathrm{~kg}$ were arranged in a Latin Square $4 \times 4$ with 4 treatments and 4 animals. The animal were housed in four individual cages. Feed used in this experiment were formulated from agricultural and food industry byproducts i.e. fish waste, soybean curd waste, taro skin, soybean skin, vegetables waste and commercial pig feed. The agricultural and food industry byproducts were collected from 2 traditional markets and 4 food industries. The four treatments wereP1: 100\% commercial feed (control) P2: combination of $25 \%$ agricultural and food industry wastes and $75 \%$ commercial feed; P3: combination of $50 \%$ agricultural and food industry wastes and $50 \%$ commercial feed; P4: combination of $75 \%$ agricultural and food industry wastes and $25 \%$ commercial feed. Feeds P2, P3 and P4 were formulated based on dry matter basis with isoprotein and isoenergy concept. The commercial pig feed (CP 512) used in this experiment was produced by Charoen Pokphand, Indonesia. The formulation of pig feed in grower period is presented in Table 1.

Table 1. The nutrients content of ingredients in pig feed

\begin{tabular}{|c|c|c|c|c|}
\hline Ingredients & $\mathrm{CP}(\%)^{1}$ & $\mathrm{EE}(\%)^{1}$ & $\mathrm{CF}(\%)^{1}$ & $\mathrm{ME}(\mathrm{kcal} / \mathrm{kg})^{2}$ \\
\hline Rice bran & 11.19 & 7.77 & 13.47 & $3,230.27$ \\
\hline Fish waste & 45.85 & 7.89 & 1.59 & $2,775.53$ \\
\hline Taro skin & 4.66 & 0.54 & 10.77 & $2,870.90$ \\
\hline Vegetables waste & 17.55 & 2.20 & 24.01 & $2,495.34$ \\
\hline Soybean curd waste & 20.56 & 12.73 & 16.42 & $3,660.25$ \\
\hline Commercial feed (CP 512) & 19.00 & 5.00 & 7.00 & $3,200.00$ \\
\hline
\end{tabular}

${ }^{1}$ Dry matter basis

${ }^{2}$ Based on calculation

P1: $100 \%$ commercial feed (CP 512)

P2: combination of $25 \%$ agricultural and food industry wastes and $75 \%$ commercial feed

P3: combination of $50 \%$ agricultural and food industry wastes and $50 \%$ commercial feed

P4: combination of $75 \%$ agricultural and food industry wastes and $25 \%$ commercial feed

Table 2. The composition of grower pig feeds (\%)

\begin{tabular}{lrrrr}
\hline & \multicolumn{3}{c}{ Feeds } \\
\cline { 2 - 4 } Ingredients & $\mathrm{P} 1$ & $\mathrm{P} 2$ & $\mathrm{P} 3$ & 10.8 \\
\hline Fish waste & 0 & 3.7 & 7.2 & 28.1 \\
Soybean curd waste & 0 & 9.5 & 18.8 & 14.0 \\
Taro skin & 0 & 5.0 & 9.5 & 6.0 \\
Vegetables waste & 0 & 1.9 & 3.9 & 16.0 \\
Rice bran & 0 & 4.9 & 10.5 & 25 \\
Commercial feed* & 100 & 75 & 100.0 \\
\hline Total & 100 & 100.0 & 100.0 \\
\hline *CP 512 (Charoen Pokphand, Indonesia) & & & \\
P1: $100 \%$ commercial feed (CP 512) & & \\
P2: combination of 25\% agricultural and food industry wastes and 75\% commercial feed & \\
P3: combination of 50\% agricultural and food industry wastes and 50\% commercial feed \\
P4: combination of 75\% agricultural and food industry wastes and 25\% commercial feed
\end{tabular}


The feeds were formulated iso-energy and iso-protein according to the requirement of the grower pig period, which was $3200 \mathrm{kcal} / \mathrm{kg}$ and 18-19\% (NRC, 2012). In order to effectively compete with commercial feed, the limits of crude fiber were also taken into account in this study. According to Katsoulis et al. (2016), the maximum limit of crude fiber contained in the concentrate is less than $18 \%$. In this study the crude fiber used was a maximum of $11.65 \%$. The chemical composition of grower pig feed presented in Table 3.

\section{Experimental Procedure}

The experiment was carried out for 4 periods, each period consisted of 7 days of adaptation and 7 days of data collection in 4 treatments, so that the whole experiment lasted for 56 days. The feeds offered twice a day (at 08:00 and 16:00 h) ad libitum. Fresh water are available ad libitum. Individual feed refusals, if any, were collected, weighed daily and samples werecollected for analysis. Before the start of the experiment, pigs were dewormed with $0.7 \mathrm{ml} / \mathrm{kg}$ BW of Albendazole (PT. Kimia Farma, Indonesia). The animals were weighed each week throughout of the experiment.

\section{Statistical Analysis}

The data obtained were analyzed using variance analysis according to the Latin Square Design using the SPSS program. Duncan multiple range test was used to determine the differences between treatment when $\mathrm{P}<0.05$

The mathematical model of the experimental design used as follows:

$$
\text { Yij } \quad: \mu+B i+W i+P i+E i j k
$$

Where :

Yij : the score for observation of $i^{\text {th }}$ variableand $j^{\text {th }}$ replication

$\mu \quad$ : the overall population mean

$\mathrm{Pi} \quad$ : effect of treatments $\mathrm{i}^{\text {th }}(\mathrm{P} 1, \mathrm{P} 2, \mathrm{P} 3$ and $\mathrm{P} 4)$

$\mathrm{Bi}$ : effect of animal unit (pig 1,2,3 and 4)

Wi : effect of period(period 1,2, 3 and 4)

عij : the error effect associated with $\mathrm{i}^{\text {th }}$ treatment level and $\mathrm{j}^{\text {th }}$ replication.

$$
\begin{aligned}
& \text { i }: 1,2,3,4 \\
& \text { j : } 1,2,3
\end{aligned}
$$

\section{Results and Discussion}

\section{Feed Consumption}

Feed consumption is the difference between the amount of feed given and the amount of feed remaining. Feed consumption by pig for each treatment at age 14,16, 18 and 20 weeks is shown in Table 4.

Table 3. Chemical composition of agricultural and food Industry wastes-based feedof grower pig

\begin{tabular}{lrrrr}
\hline Composition & \multicolumn{3}{c}{ Treatments } \\
\cline { 2 - 5 } & P1 & P2 & P3 & P4 \\
\hline Moisture (\%) & 6 & 8.3 & 8.64 & 8.97 \\
Crude protein (\%) & 19.00 & 19.00 & 18.99 & 18.99 \\
Ether extract (\%) & 5 & 5.7 & 6.42 & 7.14 \\
Crude fiber (\%) & 7 & 8.53 & 10.09 & 11.65 \\
Metabolizable energy( kcal/kg) & 3200 & 3199.99 & 3200 & 3200 \\
\hline P1: 100\% commercial feed (CP 512) & \multicolumn{5}{r}{} \\
P2: combination of 25\% agricultural and food industry wastes and 75\% commercial feed \\
P3: combination of 50\% agricultural and food industry wastes and 50\% commercial feed \\
P4: combination of 75\% agricultural and food industry wastes and 25\% commercial feed
\end{tabular}


Table 4. Feed consumption and average daily gain (g/head/day) of grower pig

\begin{tabular}{|c|c|c|c|c|c|c|}
\hline \multirow{2}{*}{ Variables } & \multicolumn{4}{|c|}{ Feeds } & \multirow{2}{*}{ SEM } & \multirow{2}{*}{ P-value } \\
\hline & P1 & P2 & P3 & P4 & & \\
\hline Feed consumption & 1941.7 & 1808.8 & 1694.8 & 1726.7 & 108.23 & 0.441 \\
\hline Average daily gain & 785.7 & 723.2 & 671.4 & 732.1 & 64.37 & 0.684 \\
\hline \multicolumn{7}{|c|}{ P1: $100 \%$ commercial feed (CP 512) } \\
\hline \multicolumn{7}{|c|}{ P2: combination of $25 \%$ agricultural and food industry wastes and $75 \%$ commercial feed } \\
\hline \multicolumn{7}{|c|}{ P3: combination of $50 \%$ agricultural and food industry wastes and $50 \%$ commercial feed } \\
\hline \multicolumn{7}{|c|}{ P4: combination of $75 \%$ agricultural and food industry wastes and $25 \%$ commercial feed } \\
\hline
\end{tabular}

Table 4 shows the highest average feed consumption found in treatment $\mathrm{P} 1$ which pig fed $100 \%$ commercial feed (CP512), which was $1941.68 \mathrm{~g} / \mathrm{head} /$ day. This amount of consumption was still lower than the value of $2.15 \pm 0.10 \mathrm{~kg} / \mathrm{head} /$ day as reported by Pierozan et al. (2016). One of the causes of feed consumption variations is the temperature.Increasing environmental temperature will reduce the level of feed intakes (Le Bellego et al., 2002; Perondi et al., 2016). In this study the pigs were kept at a temperature of approximately $37^{\circ} \mathrm{C}$.

Furthermore, it can be seen that the increasing percentage of food waste shows a trend decreasing feed consumption. This decrease in feed consumption could be due to the characteristic of food and agricultural waste which has a lower taste quality than commercial feed. One way to increase palatability is by giving flavor which is useful for flavor enhancement (Figueroa, 2019). In the future, it is necessary to consider the need to add food flavor enhancers to agricultural and food wastes that will be used as feeds.

Another reason for the reduction in feed consumption with inclusion waste is due to the form will be powdery.In the previous study, Hancock et al. (2001) stated that pellet feed will increase feed intake because it can prevent pig from sorting the feed so that it can prevent wasted feed. Feed in the form of pellet prevents pigs from sorting feed and removing it (Grumm et al., 2008). In addition, pellet also has particle sizes that are easily swallowed and can increase nutrient digestibility. Therefore, in the future management it is very important to manage food and agricultural wastes as pig feed with a shape and size in the form of pellet so that prevent useless waste.

Based on the results of variance analysis, there was no significant difference in consumption of feeds by pigs between feed treatments. This shows that the variation in feed quality both the palatability aspect and the form of feed aspects are still within the tolerance of the grower pig.

\section{Body Weight Gain}

The effect of the treatment on the average daily gain is shown in Table 4. The results of this study showed that the highest daily gain in treatment P1 was in feeding $100 \%$ of commercial feed (CP 512), but the results of analysis of variance of the effect of treatment on daily gain showed no significant difference. This shows the ability of the pig grower in digesting and utilizing feed consumed into meat and other organs was relatively similar in combination feeds of $25 \%, 50 \%, 75 \%$ of agricultural wastes in complete feed and $100 \%$ commercial feed.

The average daily gain at the age of 14 to 20 weeks from this study was $728.13 \mathrm{~g} /$ day. The daily gain value in this study was greater than the results of the study of Carter et al., (2017) who conducted a feeding trial of forage-based feed in pigs aged 15 to 20 weeks producing average daily gain of $160 \mathrm{~g} /$ day, also it shows a 
faster growth than the previous study by Wea (2017) that feeding market waste organic as pig feeds produced daily gain $720 \mathrm{~g} / \mathrm{head} /$ day. It can be concluded that the feeding agricultural and food industry waste-based feed to pig in Manokwari has good potential for the development of pig business in Manokwari.

\section{Feed Efficiency}

Feed efficiency is the cumulative efficiency that pigs use to utilize feed nutrients for maintenance and gain. A deeper understanding of feed efficiency is very important for pig farming because it relates to the profits that will be obtained by farmers. Besides that, information about feed efficiency is needed to assess the economic value of a feed compared to substituted feeds (Patience et al., 2015). The results of the calculation of feed efficiency in this study are shown in Table 5.

The results analysis of variance on feed efficiency showed no significant differences feed efficiency between the treatment of waste-based feed and control. So that it can be said that organic waste in Manokwari has the potential to be used as a substitute for commercial feeds without any worries that it will significantly reduce the economic value of pigs. Patience et al. (2015) stated that feed efficiency is influenced by internal and external factors of pigs. Internal factors include the condition of pig health and gender, while external factors include the amount of feed energy and form of feed. So it can be said that as long as waste-based feed is formulated and has a form equivalent to commercial feed, waste-based feed will have a high chance of being a substitute for commercial feeds.

\section{Feed Convertion}

Feed conversion is a measurement of the amount of feed needed by an animal to get one $\mathrm{kg}$ of body weight. Low feed conversion ratio shows pigs to convert feed into weight efficiently. A high feed conversion ratio means pigs may not use the potential of a feed. The results of the calculation of feed conversion are presented in Table 7.

The results of the analysis of variance showed that there was no significant difference $(P>0.05)$ in feed conversion in pigs fed feed treatment. This shows that agricultural waste and the food industry can be used as constituent materials that replace some of the commercial feeds.Based on the data in Table 1, the best value of FCR was found in the treatment of feed P4 (75\% waste, 25\% commercial feed). This shows the fact that even though the feed P4 in this study used the highest amount of waste, it has a great potential to be used as feeds for pig. Katsoulis et al., 2016 stated that although agricultural waste contains high crude fiber, it is still good to be given as feed for pigs as long as crude fiber is less than $18 \%$. Furthermore, it was also stated that crude fiber contained in agricultural wastes had a good impact on intestinal health in pigs.

Table 5. Feed efficiency and feed convertion of grower pig

\begin{tabular}{|c|c|c|c|c|c|c|}
\hline \multirow{2}{*}{ Variables } & \multicolumn{4}{|c|}{ Feeds } & \multirow{2}{*}{ SEM } & \multirow{2}{*}{ P-value } \\
\hline & P1 & $\mathrm{P} 2$ & P3 & P4 & & \\
\hline Feed efficiency & 0.41 & 0.39 & 0.39 & 0.43 & 0.04 & 0.92 \\
\hline Feed convertion & 2.47 & 2.50 & 2.52 & 2.36 & 0.32 & 0.90 \\
\hline
\end{tabular}


Table 6. Feed costs during maintenance of grower pigs and the reduction level of waste-based feed to commercial feed

\begin{tabular}{crrrrrr}
\hline Treatments & $\begin{array}{c}\text { Feed cost } \\
\text { (IDR/kg) }\end{array}$ & \multicolumn{3}{c}{ Feed cost per head per day (IDR)/period } & $\begin{array}{c}\text { Reduction } \\
\text { of feed } \\
\text { cost to } \\
\text { commercial } \\
\text { feed (\%) }\end{array}$ \\
\cline { 3 - 7 } & & \multicolumn{1}{c}{ I } & II & III & IV & $0.00^{\mathrm{a}}$ \\
\hline P1 & $11,000.00$ & $23,411,190.00$ & $16,588,000.00$ & $21,635,460.00$ & $23,799,270.00$ & $19.82^{\mathrm{b}}$ \\
P2 & $9,467.05$ & $15,260,884.60$ & $15,212,223.96$ & $18,221,325.81$ & $19,802,323.16$ & $36.92^{\mathrm{c}}$ \\
P3 & $7,949.86$ & $10,703,930.00$ & $11,890,685.10$ & $13,127,524.32$ & $18,171,074.50$ & $48.00^{\mathrm{c}}$ \\
\hline
\end{tabular}

P1: $100 \%$ commercial feed (CP 512)

P2: combination of $25 \%$ agricultural and food industry wastes and $75 \%$ commercial feed

P3: combination of $50 \%$ agricultural and food industry wastes and $50 \%$ commercial feed

P3: combination of $70 \%$ agricultural and food industry wastes and $25 \%$ commercial feed

Means with different superscript in the same row differ significantly $(P<0.05)$

\section{Costs of Agricultural Waste-based Feed for Grower Pig}

Feed cost analysis during the maintenance period of grower pigs and the amount of feed cost reduction can be seen in Table 8.

The result of the variance analysis for the use of agricultural and the food industry wastes in feed showed that there were significant differences $(P<0.05)$ between the treatments of P2, P3, P4 and P1 (control) on the performance of the grower period pigs. The results of the study by Patience et al. (2015) showed that the proportion of feed costs reached 60 and $70 \%$ of the total cost of pork production. The high cost of feed can be rationalized by finding alternative sources of feed that can reduce feed costs, without reducing the quality of the production. The role of agricultural and the food industry wastes as feed that can substitute commercial feed can be seen in Table 6 .

Feed cost analysis on the three types of waste-based feed treatment showed that $\mathrm{P} 2$, P3 and P4 feeds were able to reduce feed costs by $19.82 \%, 36.92 \%$, and $48.00 \%$, respectively. In Manokwari the commercial feed has a price of IDR 11,000 per $\mathrm{kg}$ and it is not available continuously. Considering that the potential for traditional market and the food industry wastes is sufficiently adequate, the use of agricultural waste and the food industry in Manokwari can be sought to be processed in order to increase feed availability continuously. It is necessary to work with the local government to create a center for collecting agricultural waste in the main markets which are mostly found in vegetable and fish wastes that have not been managed properly. The use of waste is expected to have a positive impact not only for the development of pigs that are important for the people of Papua in Manokwari but also will increase the aesthetic value of the environment for the Manokwari city.

\section{Conclusions}

Results of this study showed that there were no significant difference between the grower pigs' performances, whether they are fed with agricultural and food industry wastes or with commercial feed. Agricultural and the food industry wastes can be a substitution feed for commercial feed as long as they pay attention to the nutritional aspects of the grower pig. Feeding treatment with the combination of $75 \%$ waste and $25 \%$ commercial feed gave the best average feed convertion ratevalue of2.36, Feed Efeciency 0.43 and had the most economic 
price, and could reduce the feeding cost up to $48 \%$.

\section{Acknowledgement}

This study was funded by The Directorate General of Strengthening Research and Development, Ministry of Research, Technology and Higher Education of Indonesia through "Hibah Produk Terapan" scheme (contract number 080/SP2H/LT/DRPM/2018).

\section{References}

Carter NA, CE Dewey, D Grace, C Wel, B Lukuyu, E Smith and CFM de Lange. 2017. Average daily gain and the impact of starting body weight of individual nursery and finisher Ugandan pigs fed a commercial diet, a forage-based diet, or a silage-based diet. Journal ofSwine Health Production25:121-128.

Directorate General of Livestock and Animal Health. 2017. Livestock and Animal Health. Statistics. Directorate General of Livestock and Animal Health. Ministry of Agriculture, Indonesia.

Faculty of Animal Science, Fishery and Marine Science. 2014. Study the Potency of Local Feed for Development Pig Farm in Manokwari Regency. Research Report. Faculty of Animal Science, Fishery and Marine Science, State University of Papua.

Figueroa J, D Frías, D Solà-Oriol, T Tadich, R FrancoRosselló, V Nuñez and DM Dwyer. 2019. Palatability in pigs, the pleasure of consumption. Journal of Animal Science 97:2165-2174.

Grumm MC, SL Colgan and KJ Bruns. 2008. Effect of out-of-feed events and diet particle size on pig performance and welfare. Journal of Swine Health Production (2):72-80.

Gustavsson J, C Cederberg, U Sonesson, R van Otterdijkand A Meybeck. 2011. Global food losses and food waste: extent, causes and prevention, Food and Agriculture Organisation of the United Nations (FAO), Rome. p. 29.

Hancock JD and KC Behnke. 2001. Use of ingredient and diet processing technologies (grinding, mixing, pelleting and extruding) to produce quality feeds for pigs. In: Swine Nutrition. (A.J. Lewis and L.L. Southern, eds.), $2^{\text {nd }}$ edition. CRC Press LLC. Boca Raton. Florida.
Katsoulis K, L Leontides and G Kontopindis. 2016. Locally produced agricultural by-product as feed sources for pigs. Journal ofVeterinary Science and Medicine 4:1-5.

Kueain YA, IK Suamba and PU Wijayanti. 2017. Business financial analysis on piggery (A case study of piggery of UD Karang at Jagapati village, Sub-District of Abiansemal, Badung). Jurnal Agribisnis dan Agrowisata 6:96-104.

Le Bellego L, J van Milgen, S Duboisand J Noblet. 2001. Energy utilization of low-protein diets in growing pigs. Journal of Animal Science 79:12591271.

National Research Council (NRC). 2012. Nutrient Requirements of Swine: Eleventh Revised Edition. Washington, DC: The National Academies Press.

Patience JF, MC Rossoni-Serão and NA Gutiérrez. 2015. A review of feed efficiency in swine: biology and application. Journalof Animal Science and Biotechnology 6:33-43.

Perondi D, M Kipper, I Andretta, L Hauschild, R Lunedo, CS Franceschina and A Remus. 2018. Empirical models to predict feed intake of growing-finishing pigs reared under high environmental temperatures. Science Agriculture 75 (4):296-303.

Pierozan CR, PS Agostini, J Gasa, AK Novais, CP Dias, RSK Santos, M Pereira Jr, JG Nagi, JB Alves and CA Silva. 2016. Factors affecting the daily feed intake and feed conversion ratio of pigs in growfinishing units: the case of a company. Porcine Health Management 2: 1-8.

Stenmarck A, C Jensen, T Quested and G Moates. 2016. Estimates of European Food Waste Levels. IVL Swedish Environmental Research Institute.

Thi NBD, G Kumar and C-Y Lin. 2015. An overview of food waste management in developing countries: current status and future perpective. Journal of Environmental Management157: 220229.

Venkat K. 2011. The climate change and economic impact of food waste in The United States. International Journal on Food System Dynamics 2: 431-446.

Warouw ZM, VVJ Panelewenand ADP Mirah. 2014. Pig farm analysis of Kasewean company at Kakaskasen II of Tomohon Municipality. Jurnal Zootek 34:92-102.

Wea R. 2017. Production performance of pigs' which consume market's organic wastes. Partner Journal 20:127-135. 